\title{
Mosses flora of coal dumps of Kuzbass
}

\author{
Alexey Nozhinkov*
}

The Federal Research Center of Coal and Coal Chemistry of Siberian Branch of the Russian Academy of Sciences, 650065, Kemerovo, Leningradskiy pr., 10, Russia

\begin{abstract}
The floristic structure of mosses on overgrown coal dumps of the Kemerovo region in three natural zones has been studied. The features of the behavior of a number of species in the conditions of anthropogenically altered communities are noted. A species included in the Red Data Book of the region has been identified.
\end{abstract}

\section{Introduction}

Human economic activity inevitably leads to the fact that significant areas of the earth's surface are disturbed. The greatest changes are taking place in the regions where mining operations are carried out - ore or fossil fuel. The Kuznetsk Basin is the largest in Russia, both in terms of the amount of coal reserves and in terms of production. In open pit mining, in addition to open pits, huge areas are occupied by dumps of overburden rocks. After some time, areas devoid of natural vegetation cover, and often of soil, begin to be populated by the most active plants and lichens. In the group of pioneer species, bryophytes play a significant role.

The aim of the research was to study the floristic composition of mosses growing on dumps.

\section{Materials and Methods}

The objects of study are located in three natural subzones: the southern forest-steppe "steppe core of the Kuznetsk depression" (dumps of the Vakhrushevsky and Karagailinsky open-pit mines), the northern forest-steppe (Kedrovsky and Chernigovsky coal open-pit mines) and taiga (Krasnogorsky and Sibirginsky open-pit mines).

\section{Results and discussion}

A total of 36 species of mosses were found on the studied dumps. The distribution by points is shown in Table 1.

Table 1. Distribution of mosses on coal dumps

\begin{tabular}{|l|l|}
\hline Abietinella abietina $(\mathrm{Hedw}$.$) Fleisch.$ & 2 \\
\hline Amblystegium serpens (Hedw.) Bruch. et al. & 1,2 \\
\hline Aulacomnium palustre (Hedw.) Schwägr. & 4,6 \\
\hline
\end{tabular}

${ }^{*}$ Corresponding author:: alexbryo@yandex.ru 


\begin{tabular}{|c|c|}
\hline Barbula unguiculata Hedw. & $1,2,6$ \\
\hline Brachytheciastrum velutinum (Hedw.) Ignatov et Huttunen & 6 \\
\hline Brachythecium cirrosum (Schwägr.) Schimp. & 4 \\
\hline Brachythecium mildeanum (Schimp.) Schimp. ex Milde & 2 \\
\hline Brachythecium rotaeanum De Not. & 2 \\
\hline Brachythecium salebrosum (F.Weber et D.Mohr) Bruch. et al. & $1,2,3,6$ \\
\hline Bryum argenteum Hedw. & $1,2,6$ \\
\hline Bryum caespiticium Hedw. & $1,2,3,6$ \\
\hline Callicladium haldanianum (Grev.) Crum & 5 \\
\hline Calliergonella lindbergii (Mitt.) Hedenäs & 4 \\
\hline Ceratodon purpureus (Hedw.) Brid. & $1,2,6$ \\
\hline Didymodon fallax (Hedw.) Zander & 1 \\
\hline Eurhynchium angustirete (Broth.) T. Kop. & 4 \\
\hline Funaria hygrometrica Hedw. & 4 \\
\hline Leptodyctium riparium (Hedw.) Warnst. & 1,6 \\
\hline Leskea polycarpa Hedw. & 2 \\
\hline Lewinskya elegans (Schwägr. ex Hook. \& Grev.) F. Lara, Garilleti \& Goffinet & 2 \\
\hline Niphotrichum canescens (Hedw.) Bednarek-Ochyra \& Ochyra & 4,5 \\
\hline Nyholmiella obtusifolia (Brid.) Holmen \& E. Warncke & 2,3 \\
\hline Oxyrrhynchium hians (Hedw.) Loeske & 6 \\
\hline Plagiomnium cuspidatum (Hedw.) T.Kop. & $1,2,6$ \\
\hline Platydictya subtilis (Hedw.) H.A. Crum & 1 \\
\hline Pleurozium schreberi (Brid.) Mitt. & 5 \\
\hline Pogonatum urnigerum (Hedw.) P.Beauv. & 4 \\
\hline Polytrichum juniperinum Brid. & 4 \\
\hline Pseudoleskeella nervosa (Brid.) Nyh. & 2 \\
\hline Pterygoneurum ovatum (Hedw.) Dix. & 1 \\
\hline Ptilium crista-castrensis (Hedw.) De Not. & 5 \\
\hline Pylaisia polyantha (Hedw.) Bruch et al. & 3 \\
\hline Sanionia uncinata (Hedw.) Loeske & 2 \\
\hline Sciuro-hypnum oedipodium (Mitt.) Jaeg. & 4 \\
\hline Syntrichia ruralis (Hedw.) Web. et Mohr & 2 \\
\hline Thuidium recognitum (Hedw.) Lindb. & 3 \\
\hline
\end{tabular}

Legend: 1. Vakhrushevsky coal mine, vicinity of Kiselevsk town; 2. Karagailinsky coal mine, Prokopyevsk district, vicinity of Karagaila settlement; 3. Kedrovsky coal mine, Kemerovo, Kedrovka microdistrict; 4. Krasnogorsk coal mine, Mezhdurechensk urban district; 5. Sibirginsky coal mine, Mysky urban district, village Chuvashi.; 6. Chernigovskiy coal mine, town Berezovsky.

On the dump of the Vakhrushevsky coal mine, located in the southern forest-steppe, Pterygoneurum ovatum, a species specific for arid regions, was found. The species is quite rare in zonal communities has a high vitality, other species are in a depressed state.

On dumps near the village Karagayla for 30 years in, a young birch forest has formed, in which the thickness of the tree trunks, as well as the sculpture of the bark, allows bryophytes to colonize their butts. The epiphytic mosses Lewinskya elegans, Nyholmiella obtusifolia and Pylaisia polyantha were collected here. In a study on the resistance of epiphytes to atmospheric pollution in cities, these mosses are noted as the most resistant (Tamm, 1984). Here, on the trunk of a birch, Leskea polycarpa was found, a species that is given for waste heaps of coal mines in Ukraine (Boyko, 1991). In Siberia, according to our observations, this moss grows epiphytically, less often on humus soil, it was not collected on rocky substrates. 
The moss vitality is average; pleurocarpous mosses of the genus Brachythecium have welldeveloped sporogones. For a number of species (Plagiomnium cuspidatum, Amblystegium serpens, Brachythecium mildeanum, Leptodyctium riparium, Oxyrrhynchium hians) habitats with increased moisture are required, which, despite the general dryness of the dumps, still exist. It is these pleurocarpous species that achieve any significant projective cover, since they have more chances to gain a foothold on the sandstone that is subject to destruction.

In the northern forest-steppe, on the dumps of the Chernigovskiy coal mine, Aulacomnium palustre, a moss typical for swampy forests and swamps, was found. Its habitat has become recultival plantings of pine, almost devoid of grass cover, the rocks are covered with a powerful pillow of perennial litter of needles. The prevailing environmental conditions and water regime, allow this hygrophytic species to grow, moreover, with rather large tufts with high vitality.

The largest number of mosses was found in the dumps of the Karagailinsky coal mine, located in the southern forest-steppe. The most active species in the settlement of dumps belong to the genus Bryum. Some of them (Bryum argenteum) have special adaptations for vegetative propagation under trampling conditions. Amentaceous twigs are easily fragmented and can be transported over a considerable distance.

The emergence of specific habitats alters the activity of the species. For example, the steppe moss Barbula unguiculata is almost everywhere superior to the cosmopolitan Ceratodon purpureus, which usually occupies similar habitats. Both species have abundant, well-developed sporogones with high vitality.

The determining factor influencing the overgrowing of disturbed areas is humidity. The advantage is gained by species that have adaptations for survival in extremely dry conditions - a small size to reduce evaporation, hairs from dead cells or even a dying part of the apex to quickly absorb moisture, papilla (thickening of the walls) on the cells of the leaf blade. These dump species include Barbula unguiculata, Bryum argenteum, and Syntrichia ruralis.

\section{Conclusion}

Mosses are an important component of regenerating dump ecosystems. Of course, they settle in more favorable habitats and from there begin to expand over the surface of the dumps. At the first stage, ground mosses predominate; as birch forests form, typical epiphytic mosses appear on the dumps, the number of species increases, and their ecological role increases.

In the south of the region, in the taiga zone, under conditions of more intense moisture, the overgrowing of dumps with bryophytes occurs much more intensively. So, even in open areas, large areas are occupied by Niphotrichum canescens. The species of the Grimmiaceae family are characteristic of the rocky substrate, but are not found on dumps in other areas of the region. Also here, on the territory of the Sibirginsky open mine, typical forest species such as Callicladium haldanianum, Pleurozium schreberi, and Ptilium crista-castrensis were found.

Eurhynchium angustirete, a species included in the Red Data Book of the Kemerovo Region (2021), was discovered by KuzBG employees on the overgrown dumps of the Krasnogorsk coal mine.

The studies is carried out according to of the state assignment of the Russian Foundation for Basic Research and Administration of Kemerovo Region (grant №20-44-420007 r_a), and within the State assignment №0286-2021-0010 (state registration no. AAAA-A21-121011590010-5), on the base of the USU №508667 «Herbarium of the Kuzbass Botanical Garden (KUZ)»

\section{References}

1. M.F. Boyko, Ecology, 21-25 (1991) 
2. L.Yu. Prudnikova, Technology of quality of life, 1, 55-57 (2001)

3. Red Data Book of the Kemerovo Region. Rare and endangered species of plants and fungi (Kemerovo, 2021)

4. K.E. Tamm, Flora and groupings of lower plants in natural and anthropogenic environmental conditions, 203-220 (1984) 